\title{
Modelling Extreme Winners and Extreme Losers in New Zealand Stock Exchange
}

\author{
$\underline{\text { S. Abidin }}^{\text {a }}$, and T. Nguyen ${ }^{\text {a }}$ \\ ${ }^{a}$ Department of Finance, Waikato Management School, The University of Waikato, Hamilton, New Zealand \\ Email: sazali@waikato.ac.nz
}

\begin{abstract}
This paper analyses both common factors and differencing factors that can assist in identifying extremely good performance stocks and extremely poor performance stocks on New Zealand Stock Exchange market (NZX). Adopting the two-stage approach of Beneish, Lee, and Tarpley (2001), the study firstly estimates a model that is able to identify extreme performers relative to a control group within the fourth quarter each year starting from 1994 to 2010. In the second stage, this study contrasts extreme winners and extreme losers within the subset of predicted extreme performers. Findings of the study show that extreme samples are found to have lower market capitalization, lower price before portfolio formation date, and less number of available estimates. In addition, stocks belong to Winners' sample is expected to have lower closing price before the portfolio formation date than Losers' stocks. Extreme samples are also found to have higher standard deviation of return in the prior 6 months before the formation date, and higher ratio between highest closing price and lowest closing price in prior 30 days before the portfolio formation date. Findings of this study are beneficial to fund managers and investment analysts in portfolio construction and stock picking strategies.
\end{abstract}

Keywords: Extreme stocks; firm characteristics, trading characteristics; market multiples, fundamental variables 


\section{INTRODUCTION}

Beneish, Lee, and Tarpley (2001) found great disparity between the performances of stocks listed on the United States Stock Exchange in a typical quarter. In addition, they also found several sufficient indicators for distinguish performance of stock prices (in term of size adjusted return). These extreme stocks are of particular interest to professional fund managers and investors. The purpose of this study is similar to Beneish et al (2001) study. However, instead of digging into the US stock markets, which was investigated by number of previous studies, this study totally focuses on New Zealand Stock Exchange market (NZX) by analysing both common factors and differencing factors that can assist in identifying extremely good performance stocks and extremely poor performance stocks.

In this study, the two-stage approach of Beneish, Lee, and Tarpley (2001) is the main foundation techniques with additional modifications on variables use such as dropping NASVOL and slightly differences in calculating size adjusted return. The modification of some variables is mainly due to the differences between the US stock markets and the NZX. In the first stage, the study estimates a model that is able to identify extreme performers relative to a control group within the fourth quarter each year starting from 1994 to 2010. In the second stage, this study then contrasts extreme winners and extreme losers within the subset of predicted extreme performers. The dependent variable is size adjusted return (RNTQ4), which is calculated for all public-listed stocks on New Zealand Stock Exchange. The sample extends from 1994 to 2010 and consists of 1,368 observations. The size adjusted return represents the difference between the firm's buy-andhold returns and the buy-and-hold return on a value-weighted portfolio of firms in the same CRSP size decile. The analysis methods are used in this study for prediction of extreme stock returns. Even if gains and losses from holding them can be dramatic, little is known about the characteristics of these stocks (Beneish, Lee, \& Tarpley, 2001). It will then be examined to which existing market anomalies, such as the price-tobook effect and the price momentum effect are attributable to the extreme performers in the top and bottom $10 \%$ of all stocks. Also, accounting-based variables (such as R\&D, profit margins, and capital expenditures) are tested to find whether they have any influence in returns prediction across extreme and non-extreme firms within New Zealand Exchange markets.

There are three areas of research relevant to the subject matter that is addressed in this study. First, it sits in that stream of literature that has been described as contextual studies in that it addresses a particular subgroup of stocks, the extreme performers. Second it relates to the general area of predictability in that we aim to identify in advance these extreme performers where our success will undoubtedly lead to the construction of outperforming portfolios. Third, it can be regarded as part of a stream research that address the question of the relevance of accounting information, especially from the context of making investment decisions. Reingamun (1988) was the first study that sought to identify extreme winners. He used a combination of technical and fundamental factors and identified that extreme winners were most likely to come from value stocks that were enjoying strong price and earnings momentum. We expand the context beyond extreme winners to extreme performers as we first seek to identify both extreme winner and extreme losers and then differentiate between the two. Other contextual studies have been conducted in the areas such as bankruptcies (Altman et a., 1977), and mergers (Palepu, 1986).

Using cross-sectional analysis to produce factors models that forecast future returns has been the subject of many academic papers. Perhaps the most well-known academic papers in this are Fama and French (1993) and Carhart (1997) that both drew from the market anomalies literature to develop models based on value, size and momentum to explain stock returns. Other factors that researchers have found to be correlated with future markets performance include accruals (Sloan, 1996), financial health, (Bird and Casavecchia, 2007) and several macroeconomic variables (Petkova, 2006). Almost all quantitative fund managers have their own factor models which are the basis of their investment strategy. Finally our work covers much of the territory previously canvassed by papers that have attempted to assess the usefulness of accounting information in identifying the better performing stocks. Ou and Penman (1989) was the foundation paper in this area with these authors testing numerous accounting ratios and identifying some that were useful in identifying future stock returns. Several subsequent papers have confirmed the usefulness of accounting data to various degrees (Abaranell and Bushee 1998; Bird and Casavecchia 2007).

\section{LITERATURE REVIEW}

The predictability of stocks returns has occupied the minds of market participants ever since markets were established. The interests of academics in this exercise dates back more than a century but was given a fillip by the work of Fama and French (1992) who categorised the Efficient Markets Hypothesis (EMH) in the 60s 
(1970). Since that time hundreds of empirical studies using a range of methods have identified instances where stocks returns seemed to be predictable, at lease to the extent that they provide insights that can be used as the basis for strategies that can when implemented outperform the market (e.g. Lakonishok, Shleifer, and Vishny (1994); Jegadeesh and Titman (1993)). Further, these instances of predictability are frequently referred to as market anomalies in that they are at variance with the Efficient Market Hypothesis. Many would argue that this is not the case citing explanations such as the strategies do not generate excess returns once one takes account of implementation costs (Rubinstein, 2001) or that the analysis has identified spurious predictive relations (Ferson, Sarkissian, and Simin, 2003).

One answer to the second of these criticisms is to show that similar models suggest predictability across different markets at different points in time. It is this that provides a particular motivation for this paper with another equally important examining a particular instance of predictability which has previously not been examined in the context of the New Zealand Stock Exchange market. Beneish, Lee, and Tarpley (2001) examined the extent to which extreme performing stocks could be identified in advance in the US equity market. They found that both extreme winners and extreme losers share some certain characteristics that differentiate than more normal performing stocks and in turn there are a number of accounting variables which enable the extreme winners to be distinguished from extreme losers. Glickman, DiRienzo, and Ochman (2001) extended the analysis to US small cap stocks and also demonstrated the importance of the first two moment of recent performance (momentum and volatility) in first identifying, and then differentiating between, extreme performers. Becker and Ochman (2004) largely extend the Glickman, DiRienzo, and Ochman (2001) analysis to European markets pointing out that differing company characteristics and reporting practices may lead to variations between the models appropriate for European stocks as compare to those identified for the US stocks. Again, they find that a two stage process works best first identifying extreme performers using variables such as short-term volatility, age and recent sales history and then differentiating between those identified using several variables including momentum and fundamental accounting variables.

\section{DATA AND DESCRIPTIVE STATISTICS}

The research objective is to detect a descriptive profile of the firms that subsequently experience a sharp price movement. Following the study of Beneish (2001), there are total of 11 market based variables and 8 fundamental signals. Comparing to Beneish's (2001) study, the only abandon variable is NASVOL (equal AVGVOL of firms is traded on NASDAG, zero otherwise, which is not consistent with this study which investigates toward New Zealand Stock Exchange). To ensure of having sufficient number of sample the stocks, securities have close price of less than $\$ 1$ on portfolio formation date which are also included (this help to explain the negative figures for PRICE variables). These 19 variables are listed in Table 1, including data expression from Thomson One Banker.

\section{Dependent Variable}

Panel A of Table 1 presents the dependent variable: size adjusted returns in a last subsequent quarter each year (RTNQ4). This variable is the buy-hold return for a given firm in a future quarter; minus the average return for firms in the same size decile over that fiscal quarter. To ensure the accounting information is available by the portfolio formation date, the RTNQ4 is computed as over the first calendar quarter from October 01 to December 31, which is 3 months after the fiscal quarter end on September 30 each year.

\section{Independent Variables}

The independent variables derive from two main streams of research (First, from the literature on market volatility, and second, from prior literature on market pricing anomalies). These variables are grouped as either market-based signals, or fundamental signals. These two groups are intended to highlight the incremental contribution of accounting variables to the two tasks at hand.

\section{Market-based Signals}

The purpose of these market-based signals is to control for general firm characteristics and recent trading patterns that could be early ideal indicators of large imminent price movement.

The panel B of Table 1 presents four general firm characteristics including SIZE, PRICE, NUMEST, and AGE. SIZE is the decile ranking of a firm's market capitalization based on the New Zealand Stock Exchange cut-offs, as of September 30 of the prior year. PRICE is the natural log of close price just one day before portfolio formation date. NUMEST is the number of analysts supplying a one year ahead earnings forecast (assumed to be zero if firm is not available in the Thomson One Banker database). AGE is defined as the number of months from the first listing data on CRSP to the fiscal quarter end on September 30. 
The panel C presents four variables associated with recent trading activities in each stock including FRTN6, AVGVOL, STDRET, and MINMAX. FRTN6 is the size adjusted buy and hold return in the six months prior to portfolio formation ended on September 30 each year. AVGVOL is the average daily turnover ratio over the prior six months ended on September 30 each year. STDRET is the standard deviation of daily returns in the 250 trading days prior to portfolio formation. MINMAX is the ratio of the highest daily closing price to the lowest closing price over the past 30 trading days ended on September 30 each year. Panel D describes three market based valuation multiples including $\mathrm{D} / \mathrm{P}$ is the debt to market ratio; $\mathrm{B} / \mathrm{P}$ represents the book to price ration and $\mathrm{S} / \mathrm{P}$ is the sales to price ratio.

\section{Fundamental Signals}

There are total eight fundamental signals which are presented in the panel E of table 1 including: SGI, GMG, CHGEPS, ACCRUAL, R\&D, CAPX, LSY, and SLDY. SGI is the rates of sales growth over the past year. GMG is the percentage change in sales minus percentage change in gross margin. CHGEPS is a measure of the earnings surprise from the most recent year. ACCRUAL is the total accrual scaled by average total assets. $R \& D$ is a measure of research and development expenditure intensity, calculated as total research and development expenditures divided by total assets. CAPX is measured as total capital expenditures divided by average total assets. There are two extra indicator variables (LSY and SLDY) to capture possible asymmetry in the case of loss firms, or firms that have experienced sales declines. LSY is defined as value of 1 if a total earnings before interest and tax is negative over the past year and 0 otherwise. SLDY takes on the value of 1 if sales declined over the past year, and 0 otherwise.

Table 1 Variable definitions

Panel A: Dependent Variable

RTNQ4 3-month size-adjusted buy-hold returns over the calendar quarter from October 01 to December 31, 3 months after the fiscal quarter end on September 30 each year (time t). Data expression is "TF.PriceClose"

Panel B: Firm Characteristics

SIZE Decile Ranking of Market Cap as of September 30 of the year prior to portfolio formation date PRICE Natural log of price just before portfolio formation date

AGE Age of firm computed as number of months from 'BEGDAT' on CRSP to fiscal quarter end on September 30. Age data expression is "DateofIncorporation"

NUMEST Number of analysts supplying FY1 forecasts (equal 1 if found from database, or 0 if firm not in IBES database)

Panel C: Trading Characteristics

FRTN6 Prior 6-month size-adjusted buy-hold returns ended on September 30 each year

AVGVOL Prior 6-month Average Daily Turnover ended on September 30 each year. Data expression is "TF.MarketCapMonthly"

STDRET Standard deviation of daily returns over the 250 trading days prior to portfolio formation

MINMAX The ratio of the highest price to the lowest price over the past 30 trading days ended on September 30 each year

Panel D: Market Multiples

B/P The book-to-price ratio computed as total SE/MVE as of the portfolio formation date. Data expression is "TF.PricetoBookratioClose"

$\mathrm{S} / \mathrm{P} \quad$ The sales-to-price ratio computed as Net sales divided by market capitalization

D/P The debt-to-price ratio computed as (current liabilities + Long-term debt)/market capitalization

Panel E: Fundamental Variables

SGI Current period sales are divided by last year period sales $\left(\mathrm{Sales}_{\mathrm{t}} / \mathrm{Sales}_{\mathrm{t}-1}\right)$.

GMG Percentage changes in sales - Percentage changes in gross margin $(\Delta \%$ Sales $-\Delta \%$ Gross Margin)

R\&D $\quad$ R\&D expense deflated by total assets, deemed zero if missing

CHGEPS Earnings surprise $\left(\left(\mathrm{EPS}_{\mathrm{t}}-\mathrm{EPS}_{\mathrm{t}-1}\right) /\right.$ Price $\left._{\mathrm{t}-1}\right)$

ACCRUAL Total accruals/Average total asset

CAPX Capital Exp./Average total asset $\left(\mathrm{CAPX}_{\mathrm{t}} /\left(\right.\right.$ Total Asset $_{\mathrm{t}}+$ Total Asset $\left.\left.\left._{\mathrm{t}-1}\right) / 2\right)\right)$

SLDY Indicator $(=1)$ if sales decline in most recent year $\left(\operatorname{Sales}_{t}-\right.$ Sales $\left._{\mathrm{t}-1}\right)$

LSY Indicator $(=1)$ if loss (EBIT) occurs in most recent year $\left(\mathrm{EBIT}_{\mathrm{t}}-\mathrm{EBIT}_{\mathrm{t}-1}\right)$

Note: Year t refers to data from the most recent year to September 30. All \%'s calculated as follows: $\left[X_{t}-\right.$ $\left.\left(\left(X_{t-1}+X_{t-2}\right) / 2\right)\right] /\left(\left(X_{t-1}+X_{t-2}\right) / 2\right)$. 


\section{RESEARCH METHODOLOGY}

Data is mainly collected from Thomson One Banker. The sample consists of all firms in the CRSP and merged Compusat (PST, Full Coverage, and Research) universe. Following the study of Beneish et al. (2001), to ensure sample firms have sufficient market liquidity, the stock samples are required to have a stock price of at least $\$ 1$ on the portfolio formation date. However, due to limited number of available stock each year, samples with stock closing price of less than $\$ 1$ on the portfolio formation date are included in the estimated samples. After data collection and calculation, all stocks samples are re-ranked based on the size adjusted returns for each year. In the previous study of Beneish et al. (2001), based on the stock's performance, the top $2 \%$ and bottom $2 \%$ were pull-out from total estimated sample.

To ensure of having sufficient number of samples for extreme winner and loser, the top $10 \%$ and bottom $10 \%$ were pulled from total sample each year with the time period covered is from January 1994 to December 2010. After excluding inactive stocks, the total number of samples is 1683 which includes 170 samples each for extreme winners and extreme losers group, and 1343 samples for control group. Due to small scale of New Zealand exchange market, this study is trying to increase the number of estimated samples which lead to a trade-off limitation between insufficient numbers of estimated total samples or extreme samples and insufficient market liquidity requirement of securities having stock price under $\$ 1$.

\section{FINDINGS AND DISCUSSIONS}

\section{Estimated Returns for Extreme and Non-Extreme Firms}

During this contextual analysis, it contains the differential role played by number of variables for the purpose of predicting return performance of extreme and non-extreme firms. The table 3 presents the results of pooled regression of total sample of 1683 New Zealand Exchange stocks in the estimated sample from 1994 to 2010. The independent variables are including market ratio (B/P), measure of price momentum (FRTN6), measure of firm market capitalization (SIZE), and in addition with total 8 fundamentals variables as listed in table 1.

Model A and B apply simple least square regression of the some or all discussed independent variable listed in Table 1. These two models are followed to number of previous studies, especially Beneish et al. (2001) paper. The model $\mathrm{C}$ and $\mathrm{D}$ also choose the same independent variables with model $\mathrm{A}$ and $\mathrm{B}$ respectively, in addition with the set of interaction terms $\left(I^{*} y\right)$. Within the model $\mathrm{C}$ and $\mathrm{D}$, each independent variable $(y)$ is multiplied by an indicator variable $(I)$, which is set as 1 if the firms are an extreme performer in the last end quarter each year, and zero otherwise. Moreover, in model $\mathrm{C}$ and $\mathrm{D}$, the non-interactive terms express the predictive power of the variables in the non-extreme group. In a contradiction, the interactive terms signal the incremental effect of these variables for the prediction of extreme performance return.

Model A Equation

RTNQ4 = 0.024 + (-0.06)R\&D + (-0.024)LSY + (-0.048)ACCRUAL

The regression Model A has the adjusted r-square of $2.40 \%$, which explains that the movement of size adjusted return is $2.40 \%$ explained by the total 8 variables in model A.

Model B Equation

\begin{tabular}{|c|}
\hline RTNQ4 = (-0.104)R\&D + (-0.019)LSY + (-0.05)ACCRUAL + (0.033)FRTN6 \\
\hline $\begin{array}{l}\text { The regression of Model B has the adjusted r-square of } 4.37 \% \text {, which explain that the stock return is } 4.37 \% \\
\text { explained by total } 11 \text { variables in Model B. }\end{array}$ \\
\hline Model C Equation \\
\hline RTNQ4 $=0.0258+(-0.024) L S Y+(-0.04)$ ACCRUAL $+(-0.17) I * R \& D$ \\
\hline $\begin{array}{l}\text { The regression of Model } \mathrm{C} \text { has the adjusted } \mathrm{r} \text {-square of } 3.20 \% \text { which expresses that stock return behaviour is } \\
3.20 \% \text { explained by listed variables in model C. }\end{array}$ \\
\hline Model D Equation \\
\hline $\begin{array}{c}\text { RTNQ4 }=0.0242+(-0.024) \text { LSY + (-0.04)ACCRUAL + (-0.21)I*R\&D + } \\
(-0.11) I * A C C R U A L+(0.014) I * B P+(0.08) I * \text { FRTN6 }\end{array}$ \\
\hline
\end{tabular}

The regression of Model D has the adjusted r-square of $7.58 \%$, which highlights that stock return behaviour is $7.58 \%$ explained by listed variable in model $\mathrm{D}$. 
Table 3: Future returns to individual signals for all sample firms.

The table 3 presents the results of a pooled regression of 1683 New Zealand stocks in the estimated sample from 1994 to 2010. The dependent variable is the one quarter lag size adjusted returns (RTNQ1). The independent variables are the eight fundamental variables as listed in table 1, in addition of book to market ratio (B/P), a measure of price momentum (FRTN6), and a measure of firm market capitalization (SIZE). The model $C$ and $D$ included the interaction terms ( $\left.I^{*} y\right)$, in which each variable $(y)$ is multiplied by an indicator variable (I). I is equal 1 if the firm is an extreme performer (winner and loser), and zero otherwise.

Table values represent estimated coefficients ***, **, *, represents statistical significance level of confidence at $99 \%, 95 \%$, and $10 \%$ respectively, based on two-tailed tests.

\begin{tabular}{|c|c|c|c|c|}
\hline Variable & Model A & Model B & Model C & Model D \\
\hline Intercept & $0.02412 * * *$ & 0.008525 & $0.025816 * * *$ & $0.024168 * *$ \\
\hline \multicolumn{5}{|c|}{ Primary Explanatory Variables } \\
\hline SLDY & -0.0042 & 0.0005 & -0.0067 & -0.0054 \\
\hline SGI & $-0.0006 * *$ & $-0.0006 * *$ & -0.0013 & -0.0010 \\
\hline GMG & $0.0003 *$ & $0.0003 *$ & 0.0010 & 0.0007 \\
\hline $\mathrm{R} \& \mathrm{D}$ & $-0.0612 *$ & $-0.1039 * * *$ & -0.0354 & -0.0265 \\
\hline LSY & $-0.0235 * *$ & $-0.0186 *$ & $-0.0241 * *$ & $-0.0212 *$ \\
\hline CHGEPS & $6.41 \mathrm{E}-06$ & $6.85 \mathrm{E}-06$ & $-0.003698 * *$ & $-0.0037 * *$ \\
\hline ACCRUAL & $-0.0475 *$ & $-0.0504 *$ & $-0.0421 *$ & $-0.0363 *$ \\
\hline CAPX & $-0.0008 * * *$ & $-0.0007 * *$ & $-0.0007 *$ & $-0.0006 *$ \\
\hline $\mathrm{B} / \mathrm{P}$ & & $0.0062 * * *$ & & -0.0012 \\
\hline FRTN6 & & $0.0325^{*}$ & & 0.0146 \\
\hline SIZE & & $-2.95 \mathrm{E}-06$ & & $-1.22 \mathrm{E}-07$ \\
\hline \multicolumn{5}{|c|}{ Interaction Variables } \\
\hline I*SLDY & & & 0.0172 & 0.0184 \\
\hline I*SGI & & & -0.0016 & $-0.0038 *$ \\
\hline I*GMG & & & -0.0007 & -0.0005 \\
\hline I*R\&D & & & $-0.1673 *$ & $-0.2115 * *$ \\
\hline I*LSY & & & -0.0026 & -0.0003 \\
\hline I*CHGEPS & & & $0.0037 * *$ & $0.0037 * *$ \\
\hline I*ACCRUAL & & & -0.0265 & $-0.1117 * *$ \\
\hline $\mathrm{I}^{*} \mathrm{CAPX}$ & & & $-9.54 \mathrm{E}-05$ & 0.0004 \\
\hline $\mathrm{I}^{*} \mathrm{~B} / \mathrm{P}$ & & & & $0.0136 * * *$ \\
\hline I*FRTN6 & & & & $0.0813 * *$ \\
\hline I*SIZE & & & & -8.91E-06* \\
\hline Adjusted r-square & $2.40 \%$ & $4.37 \%$ & $3.20 \%$ & $7.58 \%$ \\
\hline
\end{tabular}

\section{CONCLUSIONS}

Findings from this study show that extreme samples are those that have lower market capitalization, lower price before portfolio formation date, and less number of available estimates. In addition, stocks belong to Winners' samples are expected to have lower closing price before the portfolio formation date than Losers' stocks. In the trading characteristics' variables, extreme samples are found to have higher standard deviation of return in the prior 6 months before the formation date, and higher ratio between highest closing price and lowest closing price in prior 30 days before the portfolio formation date.

For the market multiples, the higher book to price ratio might be useful for identifying extreme Winners stocks. In addition, Winners sample tend to have lower sales to price ratio toward Losers but higher sales to price ratio comparing with Control samples. This study also concludes that sales performance is not a good measure to separate extreme performers from Control samples. However, it can be used to distinguish the performance of Winners and Losers stocks, as the Winners sales growth level is expected to be lower than Losers' sales growth level. 
In the regression model, there are evidences that support the forecast of variation in future returns when it is estimated on the whole sample. Both the concluded equation model A and B agrees that the level of research and development, accrual, and EBIT growth help to indicate the stock price downward movement. The model B is different from model A in term of FRTN6. As model B suggest that 6 months prior size adjusted return might help to forecast the stock price upward movement. In addition, both equations of model C and D indicate that EBIT performance and accrual might identify control sample; and research and development help to detect extreme stock performers. The model $\mathrm{D}$ is different from model $\mathrm{C}$ in term of dummy variables of ACCRUAL, B/P, and FRTN6. As the model D suggests that variables of accrual, book to price ratio, and prior 6 months size adjusted return might be useful for separating extremely stocks from the whole samples.

For the purpose of identifying extreme sample within New Zealand stock markets, the suggested indicator are firm market capitalization, age, prior six month price adjusted return, average trading volume, standard deviation of prior 250 days return, sales growth performance, research and development, and EBIT growth. On the other hand, for the purpose of predicting negative stock return from within New Zealand stock markets, the useful indicators are its price before portfolio formation date, sales to price ratio, debt to price ratio, sales performance comparing from its prior year, and research and development expenditure. Lastly, for the purpose of separating extremely poor performance stock from extreme sample, the ideal indicators are market capitalization, and the ratio between highest and lowest closing price prior 30 days before the portfolio formation date.

\section{REFERENCES}

Abarbanell, J. S., \& Bushee, B. J. (1998). Abnormal Returns to a Fundamental Analysis Strategy. The Accounting Review, 73, 19-45. Retrieved from Proquest

Altman, E. I., Halderman R. G., and Narayanan, P. (1977). Zeta Analysis: A New Model to Identify Bankruptcy Risk of Corporations. Journal of Banking and Finance 1, 29-54. Retrieved from Proquest

Becker, Y. L., \& Ochman, R. J. (2004). Predicting extreme performers in European equities. Journal of Asset Management, 4(6), 367-391. Retrieved from ABI/INFORM Global

Beneish, M. D., Lee, C. M. C., \& Tarpley, R. L. (2001). Contextual Fundamental Analysis Through the Prediction of Extreme Returns. Review of Accounting Studies, 6(2-3), 165. Retrieved from ABI/INFORM Global

Bird, R., \& Casavecchia, L. (2007). Sentiment and Financial Health Indicators for Value and Growth Stocks: The European Experience. The European Journal of Finance, 13(8), 769. Retrieved from ABI/INFORM Global.

Carhart, M. M. (1997). On Persistence in Mutual Fund Performance. The Journal of Finance, 52(1), 57-82. Retrieved from Proquest

Fama, E. F. and French. K. R. (1992). The Cross-Section of Expected Stock Returns. Journal of Finance, 47, 427-465. Retrieved from Proquest

Glickman, D., DiRienzo, A. G., \& Ochman, R. (2001). Extreme stock returns. Journal of Asset Management, 2(2), 107-127. Retrieved from ABI/INFORM Global

Ferson, W. E., Sarkissian, S., \& Simin, T. T. (2003). Spurious Regressions in Financial Economics? The Journal of Finance, 58(4), 1393-1413. Retrieved from Proquest

Jegadeesh, N., and Titman, S. (1993). Returns to Buying Winners and Selling Losers: Implications for Stock Market Efficiency. Journal of Finance 48, 65-91. Retrieved from Proquest

Lakonishok, J., Shleifer, A., \& Vishny. R. W. (1994). Contrarian Investment, Extrapolation, and Risk. Journal of Finance 49, 1541-1578. Retrieved from Proquest

Ou, J. A., \& Penman, S. H. (1989). Financial Statement Analysis and the Prediction of Stock Returns. Journal of Accounting and Economics 11, 295-329. Retrieved from Proquest

Petkova, R. (2006). Do the Fama-French Factors Proxy for Innovations in Predictive Variables? The Journal of Finance, 61(2), 581-612. Retrieved from ABI/INFORM Global

Reinganum, M. R. (1998). The Anatomy of a Stock Market Winner. Financial Analysts Journal, March/April, 16-28. Retrieved from Proquest

Rubinstein, M. (2001). Rational markets: Yes or no? The affirmative case. Financial Analysts Journal, 57(3), 15-29. Retrieved from ABI/INFORM Global

Palepu, K. G. (1986). Predicting Takeover Targets: A Methodological and Empirical Analysis. Journal of Accounting and Economics 27, 3-36. Retrieved from Proquest

Sloan, R. G. (1996). Do Stock Prices Fully Reflect Information in Accruals and Cash Flows About Future Earnings? The Accounting Review 71, 289-315. Retrieved from Proquest 